\title{
Mid to late Holocene environmental changes along the coast of western Sardinia (Mediterranean Sea)
}

\author{
Rita T. Melis ${ }^{\mathrm{a}, *}$, Anna Depalmas ${ }^{\mathrm{b}}$, Federico Di Rita ${ }^{\mathrm{c}}$, Francesca Montis ${ }^{\mathrm{a}}$, Matteo Vacchi ${ }^{\mathrm{d}}$ \\ a Dipartimento di Scienze Chimiche e Geologiche, Università di Cagliari, Via Trentino 51, 02127 Cagliari, Italy \\ b Dipartimento di Storia, Scienze dell'Uomo e della Formazione, Università di Sassari, Via Zanfarino, 62, 07100 Sassari, Italy \\ c Dipartimento di Biologia Ambientale, Sapienza Università di Roma, Piazzale Aldo Moro 5, 00185 Roma, Italy \\ ${ }^{\mathrm{d}}$ Université P. Valéry Montpellier 3, CNRS ASM UMR 5140, Montpellier, France
}

\section{A R T I C L E I N F O}

\section{Keywords:}

Holocene

Coastal plains

Palaeoenvironmental reconstructions

Pollen

Sardinia

Western Mediterranean

\begin{abstract}
A B S T R A C T
Multiproxy analysis composed of biostratigraphy and pollen analysis allowed reconstructing the palaeoecological and palaeoenvironmental evolution of the Tirso river coastal plain in Sardinia (NW Mediterranean) in the last 6 millennia. We demonstrated that interplay between littoral and fluvial processes have significantly controlled the environmental evolution of the area and have played a key role in the pattern of historical and prehistorical settlements of this wide portion of western Sardinian coastline. At the end of Neolithic period (ca. 6.0 to $5.5 \mathrm{cal}$. ka BP) the area close to the shoreline was most likely characterized by large coastal lagoons intermittently connected to the open sea. Such saltwater influence is corroborated by faunal and pollen assemblages found in the landward portion of the Tirso coastal plain up to $2 \mathrm{~km}$ inland from the modern shoreline. Our data robustly document the end of the transgressive trend at ca. $5.5 \mathrm{cal}$. ka BP, and a dominant fluvial sedimentation since Final Neolithic period. At this time, a progradational trend started, causing the seaward migration of shoreline and, consequently, of the barrier-lagoon system. The major landscape modification tracked along the last 6 millennia may also explain the low density of historical and prehistorical remains in the Tirso coastal plain, especially if compared to the nearby rocky area of Sinis Peninsula densely inhabited since the Neolithic. Our data further provide new insights into the Relative Sea Level (RSL) evolution in this sector of the Mediterranean. In particular, we improved the mid-Holocene RSL record in Sardinia, where only scarce data were previously available.
\end{abstract}

\section{Introduction}

Mediterranean coast have represented great places for relations and exchanges among peoples, especially in historical and proto-historical periods (e.g., Masters and Flemming, 1982; Anzidei et al., 2014; Marriner et al., 2014b). In the last six millennia (i.e. mid to late Holocene) the combined effects of the slowing of sea-level rise and the increase of sediment input caused by both climatic and anthropogenic factors (e.g., Butzer, 2005; Anthony et al., 2014; Ghilardi et al., 2017) allowed the formation of large Mediterranean coastal plains that were heavily colonized by civilizations in the different pre-historical and historical periods (e.g., Brückner et al., 2006; Fontana et al., 2017; Giaime et al., 2016). Thus, coastal plains represent a very important archive of the man-environment interactions along the Mediterranean coastal landscape especially in mid to late Holocene. However, it is not easy to identify which of the natural (i.e. changes in climatic parameters, sea level changes or modification of fluvial regimes) and anthropogenic (i.e. deforestation, fires, agriculture) factors majorly influenced the landscape evolution, especially in the last 6 millennia (e.g., Hooke and Le, 2000; Brückner, 2003; Fontana et al., 2017). The aim of this study is to reconstruct the mid to late Holocene palaeoenvironmental evolution of the Tirso coastal plain, in western Sardinia, the second largest Mediterranean Island.

Sardinia, located in the center of the western Mediterranean, has always occupied a strategic position as testified by the large amount of archaeological records found along its coasts, especially from the Bronze Age to the Late Antiquity (e.g., Lilliu, 1999; Bondì, 2000; Antonioli et al., 2007). Furthermore, despite the continuous changes related to marine and fluvial dynamics, several Sardinian coastal plains have been densely settled since the Neolithic period. However, studies on the Holocene evolution of its coastal plains are seldom reported (e.g., Orrù et al., 2004). In this study, we investigated the evolution of

\footnotetext{
* Corresponding author.

E-mail addresses: rtmelis@unica.it (R.T. Melis), depalmas@uniss.it (A. Depalmas), federico.dirita@uniroma1.it (F. Di Rita), francescamontis@alice.it (F. Montis), matteo.vacchi@gmail.com (M. Vacchi).
} 
the Tirso coastal plain over the last six thousand years and its possible influence on the human settlement in the area. The Tirso coastal plain, the largest of the Island, hosts the Sa Osa archaeological site, an important settlement of the Nuragic period (i.e. 3.6-2.5 cal. ka BP, see Section 2). Further, the broad Tirso area was densely settled in the past, as testified by the impressive remains of the city of Tharros, founded by Phoenician (ca. 2.6-2.5 cal. ka BP) and subsequently occupied by Romans up to Late Antiquity (ca. 2.3 cal. ka BP, Del Vais et al., 2006).

Here we present an assessment of the environmental evolution of this important coastal area based on a multiproxy analysis of a new set of sediment cores that were chronologically constrained by ${ }^{14} \mathrm{C}$ dates. We analysed both morphological and environmental evolution of the landscape integrating sedimentological, biostratigraphical and palynological data. The results allowed elucidating the major landscape modifications of the area and their impacts on human societies in the last 6000 years. Finally, we assessed the sea-level evolution in the area by producing a new set of relative sea-level (RSL) datapoints.

\section{Study area}

The study area is located in the Tirso river coastal plain, in the northern part of the Oristano Gulf (mid-western Sardinia, Fig. 1a). The gulf represents the western boundary of the Campidano graben, a Pliocene - Quaternary structural depression oriented NW-SE (De Falco et al., 2015), filled by transitional, marine and continental deposits. The area is part of the transitional environment, bounded seaward by sandy shoreline and eastward by the Tirso alluvial plain. Several lagoons, salt and freshwater marshes, abandoned meander and backshore dunes characterize this coastal environment. Such geomorphological setting makes the whole area extremely vulnerable to sea-level rise (e.g., Antonioli et al., 2017). The tidal range is small and does not exceed $\pm 0.2 \mathrm{~m}$ (De Falco et al., 2015). In the nearby area of Sinis Peninsula, Late Pleistocene deposits (MIS 5.5, Carboni and Lecca, 1985; Ulzega and Hearty, 1986) were measured at ca. $6 \mathrm{~m}$ above present mean sea-level (msl). This implies negligible (i.e. $<0.05 \mathrm{~mm} \mathrm{a}^{-1}$ ) tectonic vertical movements in the last ca. $125 \mathrm{ka}$ (Ferranti et al., 2006).

The broad area of the Oristano gulf was intensely settled, especially in the last four millennia (Depalmas and Melis, 2010). The first evidence of intense frequentation is mainly localized in the nearby Sinis Peninsula with traces of Neolithic settlements around the Cabras Lagoon (Fig. 1a). The density of settlements increased during the Nuragic civilization (3.6-2.5 cal. ka BP). Peaks of frequentation are reported in the Middle Bronze Age (3.6-3.2 cal. ka BP), and from the Final Bronze Age to the Early Iron Age (3.1-2.7 cal. ka BP). The Nuragic age ended with the establishment of Punic settlements (ca. 2.5 cal. ka BP) along the coast and on the Campidano plain. Since the first Roman occupation (ca. 2.2 cal. ka BP) the area experienced a slow Romanization, which lasted for several centuries. On the contrary, the area was sparsely populated in the Middle Ages (Tore and Stiglitz, 1987; Stiglitz, 1998) due to the barbarian incursions. The pattern of prehistoric and historic settlements indicates a significant discrepancy between the Tirso coastal plain and the surrounding rocky area of Sinis Peninsula (Fig. 1a; Depalmas and Melis, 2010). In fact, the Sa Osa archaeological site represents the sole settlement presently found in the coastal plain (Fig. 1b). It represents a particular Nuragic settlement, built without external walls in the middle of the coastal plain and presently buried by fluvial sediments (Usai et al., 2012).

\section{Materials and methods}

We drilled 7 boreholes (S1 to S7) down to a maximum depth of $10 \mathrm{~m}$, between the shoreline and the Sa Osa archaeological site (Fig. 1b). Elevation of the cores with respect to the current mean sea level was obtained coupling GPS surveys with high resolution $( \pm 0.5 \mathrm{~m})$ Digital Elevation Model available for the whole area (Regione Sardegna, 2017). The palaeoenvironmental reconstruction was performed trough a multidisciplinary analysis of sedimentological parameters, faunal assemblages and pollen content of the cores, as already carried out on several other cases throughout the central
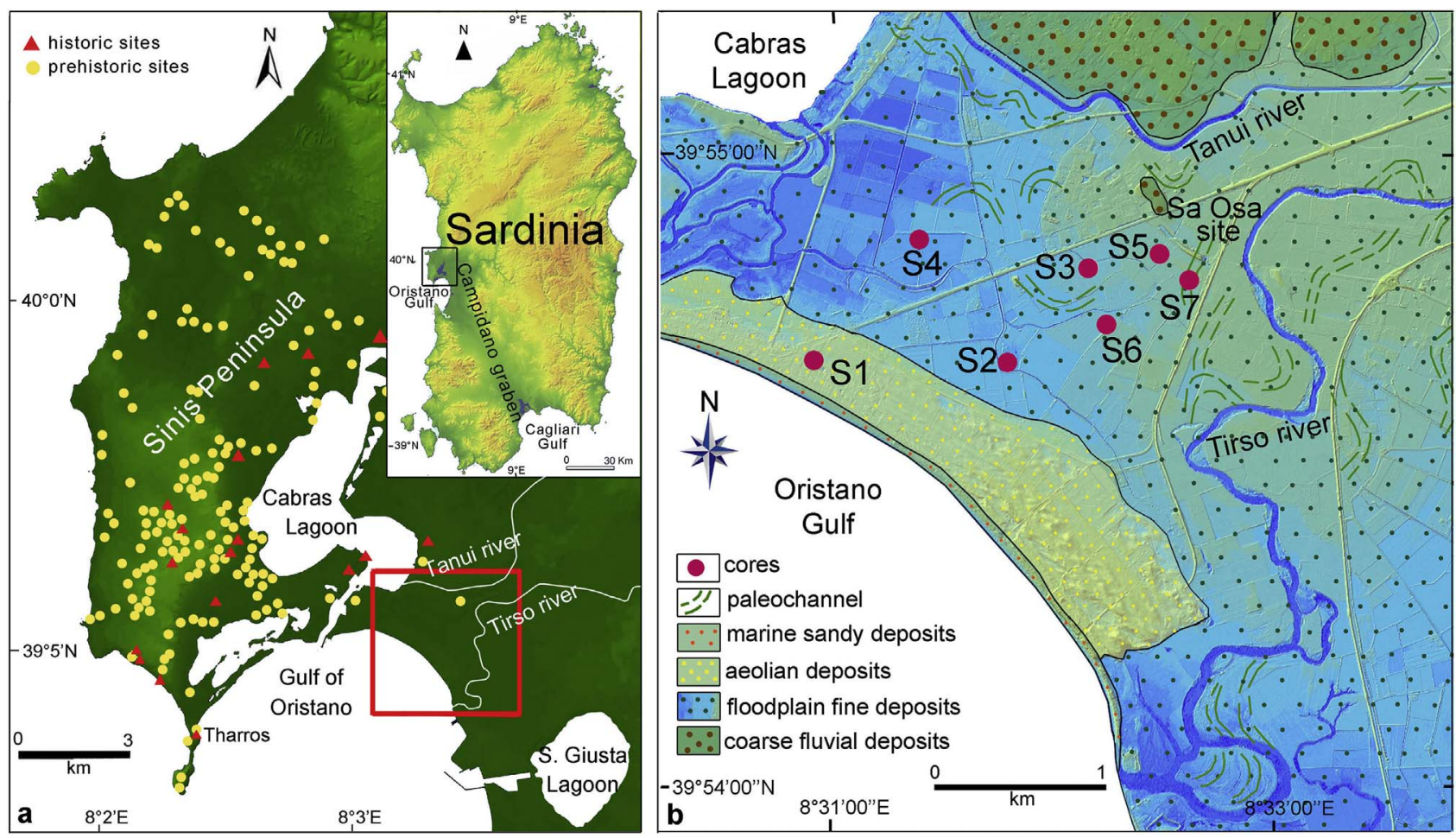

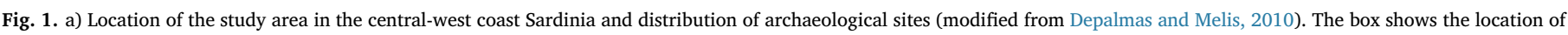

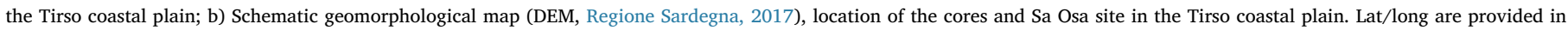
WGS84. 
Mediterranean (e.g., Di Rita et al., 2011; Amorosi et al., 2013; Currás et al., 2017). This multiproxy approach provided the framework to identify major stratigraphic units as well as to define the palaeoecological and palaeoenvironmental changes across the study area.

\subsection{Definition of the stratigraphic units}

A preliminary facies description (e.g., colour, lithofacies) was carried out under standardized laboratory conditions (see Marriner et al., 2012). Then, the 7 cores were sampled at regular $0.5 \mathrm{~m}$ interval. Dry sediments were weighed and washed through two mesh sizes, $2 \mathrm{~mm}$ and $63 \mu \mathrm{m}$, to separate out the gravels $(>2 \mathrm{~mm})$, sands $(2 \mathrm{~mm}$ to $63 \mu \mathrm{m})$ and silts and clays $(<63 \mu \mathrm{m})$ fractions. Full data are provided in Supplementary Figs. S1, S2, S3, S4, S5, S6 and S7. The different fractions were plotted against stratigraphic logs in percentages.

A biostratigraphic analysis of mollusc assemblages as well as the identification of foraminifera and ostracods along the cores was undertaken. For the macro and microfauna analysis a total of 21 samples were considered. These were collected in the most significant lithostratigraphic levels. The fraction $\geq 500 \mu \mathrm{m}$ of 20 samples of the 7 cores was used for molluscan analyses while the fraction between 63 and $500 \mu \mathrm{m}$ was observed under a stereoscopic microscope for foraminifera and ostracods identification.

Molluscs identification and definition of the ecological assemblages were performed according to the Pérès and Picard (1964), D'Angelo and Gargiulo (1978) and Doneddu and Trainito (2005) classification systems. Species determination of foraminifera and ostracods was mainly based on studies concerning the Mediterranean benthic fauna (e.g., Sgarrella and Moncharmont Zei, 1993; Fiorini and Vaiani, 2001; Fiorini, 2004). We defined the palaeoenvironmental significance of the different assemblages following the methodology used for several sedimentary archives along the central Mediterranean coasts (e.g., Donnici and Serandrei Barbero, 2002; Carboni et al., 2002; Frezza and Carboni, 2009). Full data are provided in Supplementary Tables A, B, C and D.

\subsection{Chronology of the stratigraphic units}

The age of the samples was established by a series of new 17 AMS ${ }^{14} \mathrm{C}$ radiocarbon dates taken from organic rich sediments and vegetable remains (Table 1). Because the production of atmospheric radiocarbon has varied through geological time, radiocarbon ages were calibrated to provide dates in calendar years before present. All samples were calibrated using CALIB 7.1 (Stuiver et al., 2016). In calibrating the samples of sediment, we considered that the original depositional environment was a transitional zone in the back-coastal area, influenced by fluvial processes as well as by input of marine water. Therefore for some dates a mixed IntCal13/Marine13 calibration method was applied according with the methodproposed in Di Rita et al. (2011) and Di Rita and Melis (2013). Local deviations of the marine reservoir effect were taken into account by using a $\Delta \mathrm{R}$ value of $46 \pm 40$, which is the closest $\Delta \mathrm{R}$ value (Bastia, Corsica), included in the Marine Reservoir Correction dataset (http://calib.org/marine; Stuiver et al., 2016).

\subsection{Pollen analysis}

Pollen analysis was carried out on 21 samples, which were selected as follows: 8 samples between 3.9 and $2.5 \mathrm{~m}$ from core S2, 5 samples between 8.22 and $7.2 \mathrm{~m}$ from core S5, and 8 samples between 6.78 and $6 \mathrm{~m}$ from core S7. They were chemically treated with $\mathrm{HCl}(37 \%)$, HF $(40 \%)$ and $\mathrm{NaOH}(20 \%)$, following standard procedures. Pollen concentration values were estimated by adding Lycopodium tablets to known weights of sediment. Pollen grains were identified by means of a light microscope at 400 and 640 magnifications, with the help of both pollen morphology atlas (e.g., Reille, 1992; Beug, 2004) and the reference collection of the Laboratory of Palaeobotany and Palynology of Sapienza University of Rome. The main percentage sum is based on terrestrial pollen excluding pollen of aquatics, spores of ferns and other non-pollen palynomorphs. The computer program Psimpoll 4.27 (Bennett, 2009) was used to plot the percentage pollen diagrams.

\subsection{Relative sea-level reconstruction}

Results of the palaeoenvironmental reconstructions revealed facies typical of marine, fluvial and lagoonal environments. Coastal lagoons represent a very common feature along the Sardinian coast (e.g., Di Rita and Melis, 2013; Orrù et al., 2004; Beffa et al., 2016; Buosi et al., 2017) and water depth seldom exceeds $2 \mathrm{~m}$, consistently with most of the western Mediterranean lagoons (e.g., Vacchi et al., 2016). In this study, we produced RSL index points (crf. Shennan, 1986) using samples deposited in lagoonal facies according to the standard recently proposed for the Mediterranean region (Vacchi et al., 2016). Notably, the associated indicative range for samples found open lagoon facies (i.e. high diversity in micro and meiofaunal assemblages dominated by marine and lagoonal taxa with presence of Cerastoderma glaucum, often associated with Cerithium vulgatum and Loripes lacteus) is from 0 to $-2 \mathrm{~m}$ msl (Lambeck et al., 2004, 2011; Vacchi et al., 2016). The indicative range decreases from 0 to $-1 \mathrm{~m} \mathrm{msl}$ for those samples found in semi-enclosed lagoon facies (i.e. lower diversity in the micro and meiofaunal assemblages typical of brackish estuarine and, in minor

Table 1

Radiocarbon dating results.

\begin{tabular}{|c|c|c|c|c|c|c|c|c|c|}
\hline Lab ID & Sample & Material & Depth (m) & Depth s.l.m. & ${ }^{14} \mathrm{C}$ age & $\delta 13 \times 0$ & Calibration dataset & $\%$ marine & $\begin{array}{l}\text { cal. BP (2 s) } \\
\text { age }\end{array}$ \\
\hline DSH5656 & S1a & Sediment & -6.70 & -3.60 & $3247 \pm 38$ & -28 & Intcal13 & & $3476 \pm 86$ \\
\hline DSH5661 & S1b & Sediment & -7.10 & -4.00 & $3528 \pm 38$ & -17 & Mixed Marine NoHem & $32 \%$ & $3691 \pm 127$ \\
\hline DSH5792 & S1c & Sediment & -8.80 & -5.70 & $4915 \pm 52$ & -8 & Mixed Marine NoHem & $68 \%$ & $5216 \pm 171$ \\
\hline DSH6611 & S2a & Sediment & -2.07 & -1.0 & $1187 \pm 37$ & -2 & Mixed Marine NoHem & $92 \%$ & $743 \pm 105$ \\
\hline DSH6612 & $\mathrm{s} 2 \mathrm{~b}$ & Sediment & -3.30 & -2.20 & $947 \pm 32$ & -29 & Intcal13 & & $859 \pm 66$ \\
\hline DSH5859 & $\mathrm{S} 2 \mathrm{c}$ & Sediment & -2.90 & -1.80 & $851 \pm 29$ & -54 & Intcal13 & & $794 \pm 102$ \\
\hline DSH5650 & S2d & Sediment & -6.20 & -5.10 & $5360 \pm 47$ & -13 & Mixed Marine NoHem & $48 \%$ & $5883 \pm 136$ \\
\hline DSH5657 & $\mathrm{s} 2 \mathrm{e}$ & Sediment & -8.00 & -6.90 & $6698 \pm 57$ & -17 & Mixed Marine NoHem & $32 \%$ & $7452 \pm 116$ \\
\hline DSH5659 & S2f & Sediment & -9.85 & -8.75 & $6949 \pm 69$ & -17 & Mixed Marine NoHem & $32 \%$ & $7680 \pm 121$ \\
\hline DSH5653 & S3 & Sediment & -3.25 & -1.55 & $2280 \pm 31$ & -23 & Mixed Marine NoHem & $8 \%$ & $2249 \pm 94$ \\
\hline DSH5658 & S4B & Sediment & -5.80 & -4.70 & $5556 \pm 44$ & -9 & Mixed Marine NoHem & $64 \%$ & $6060 \pm 128$ \\
\hline DSH6610 & S5a & Sediment & -7.20 & -5.15 & $5035 \pm 63$ & -3 & Mixed Marine NoHem & $88 \%$ & $5414 \pm 159$ \\
\hline DSH5788 & S5b & Sediment & -8.15 & -6.10 & $4778 \pm 35$ & -51 & Intcal13 & & $5463 \pm 130$ \\
\hline DSH6541 & $\mathrm{S} 5 \mathrm{c}$ & Sediment & -8.45 & -6.40 & $4995 \pm 24$ & -15 & Mixed Marine NoHem & $40 \%$ & $5544 \pm 68$ \\
\hline DSH6995_S & S7a & Sediment & -2.60 & -0.4 & $2662 \pm 68$ & 8 & Intcal13 & & $2744 \pm 205$ \\
\hline DSH6996_S & S7b & Sediment & -6.05 & -3.85 & $4887 \pm 35$ & -40 & Intcal13 & & $5647 \pm 63$ \\
\hline DSH6997_S & S7c & Sediment & -6.80 & -4.60 & $5402 \pm 24$ & -18 & Mixed Marine NoHem & $28 \%$ & $6065 \pm 112$ \\
\hline
\end{tabular}


terms, freshwater environment, Marriner et al., 2014a; Vacchi et al., 2016, 2017). Modern water depth of this type of brackish lagoons nearby the coring sites (such as Mistras lagoon, Di Rita and Melis, 2013) does not exceed $0.5 \mathrm{~m}$ being coherent with the proposed indicative range. Due to the difficulty in establish a direct relationship with the former msl, we used samples deposited in marine (i.e. infralittoral sands) or freshwater (fluvial sediments) environment to produce marine and terrestrial limiting points, respectively. Reconstructed RSL must fall above marine limiting points and below terrestrial limiting points (Vacchi et al., 2014).

We further added to each of these index and limiting points an additional vertical error including: i) error associated with precision in calculating the sample altitude ( $\leq \pm 0.5 \mathrm{~m}$ for our surveys) and ii) a coring error ( $\pm 0.15 \mathrm{~m}$, Vacchi et al., 2016).

\section{Results}

\subsection{Litho- and bio-stratigraphy}

The corings performed on the Tirso coastal plain have elucidated the sedimentary sequence. Here we describe the litho- and bio-stratigraphical data based on the cores S1 to S7. The facies have been subdivided into Units A, B, C, found in the S1 core, Units E, F, G, H, I found in the S2, S3, S4, S5, S6 and S7 cores. Full data of grain size analyses are provided in Supplementary Figs. S1, S2, S3, S4, S5, S6 and. S7. The faunal assemblage used to define the different units is provided in Supplementary Tables A, B, C and D respectively.

\subsubsection{S1 core}

The S1 was drilled in the modern backshore, at ca. $300 \mathrm{~m}$ from the current shoreline (Fig. 2). Three main units, all referring to littoral environment, were described along this core.

\subsubsection{Unit A: shallow marine environment $(10-6.0 \mathrm{~m})$}

Unit A is mainly characterized by alternating of light gray (2.5Y6/1) sandy levels and very fine gravelly sands (Fig. 2). This unit was described at the bottom of S1 core and the transition to the above Unit B is very gradual. The silt fraction is poor or absent and sediments are poorly sorted. Mean grain size ranges between medium to coarse sands. We observed evidence of the marine seagrass Posidonia. oceanica mixed with fragments of marine shells, dominated by Bittium reticulatum, Rissoa sp., Alvania sp., Spisula sp. and Acanthocardia sp. (Supplementary Table A). In addition, broken remains of echinoids, scaphopods (Dentalium dentalis) and corals pieces were also found in this unit. Microfossil analysis (Supplementary Table B) indicates that, through much of the unit, assemblages are dominated by benthic foraminifera (Quinqueloculina seminula, Ammonia beccarii, Elphidium crispum) and scattered valves of littoral ostracods (Ponthocythere turbida, Semicytherura spp., and rare Loxochonca elliptica). Both sedimentology and the faunal assemblages of Unit A are consistent with a shallow littoral environment between upper shoreface and foreshore with variable energy (Supplementary Fig. S1 and Table B). Three ${ }^{14} \mathrm{C}$ dates constrain the age of this unit from ca. 5.5 cal. ka BP to ca. 3.5 cal. ka BP (Table 1).

\subsubsection{Unit B: beach littoral environment $(6.0-2.6 \mathrm{~m})$}

Unit B is a sandy to fine gravelly unit occurring in S1 core from 6.0 to $2.6 \mathrm{~m}$ (Fig. 2). The grain size analysis shows unimodal or bimodal distribution with sorting ranging between well sorted to poorly sorted. Similarly, skewness ranged from symmetrical to very fine skewed (Supplementary Fig. S1). The silicoclastic sediments are composed of mainly grains of quartz, feldspar, sporadic heavy minerals and rock fragments. Shell fragments are very scarce and difficult to identify. For this reason, the definition of the depositional environment of Unit B was complex. However, according to the sedimentological features, the mineralogical composition, the roundness of grains we interpreted this unit as a beach facies, most likely deposited in an environment ranging

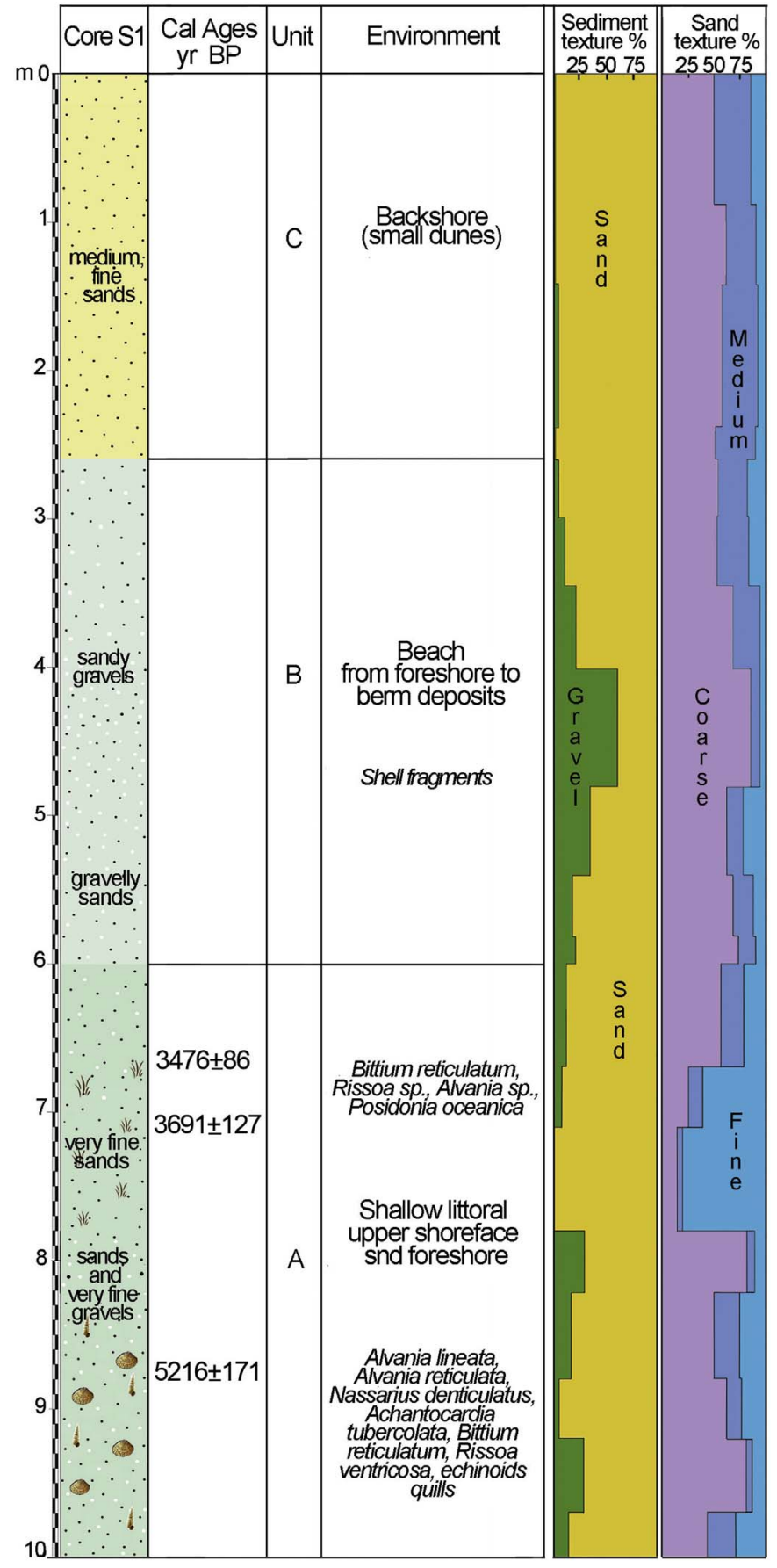

Fig. 2. Log of S1 core, lithostratigraphy and grain size analyses.

from the foreshore to a subaerial berm deposit.

\subsubsection{Unit C: backshore dunes $(2.6-0.0 \mathrm{~m})$}

Unit $C$ is quartzo-feldspathic medium sands unit, showing a very pale brown colour (10YR 7/4). Sands show unimodal size distribution, with mean grain size ranging from medium sand to coarse sand $(0,49 \div 0,61 \mathrm{~mm})$. Sediments are moderately sorted, with symmetrical skewness (Supplementary Fig. S1). There is a complete absence of biological remains in this Unit (Fig. 2). We interpret this facies as a backshore environment dominated by the wind, likely to be characterized by a system of small dunes. Such environment is very similar to the present setting of the coring site. 


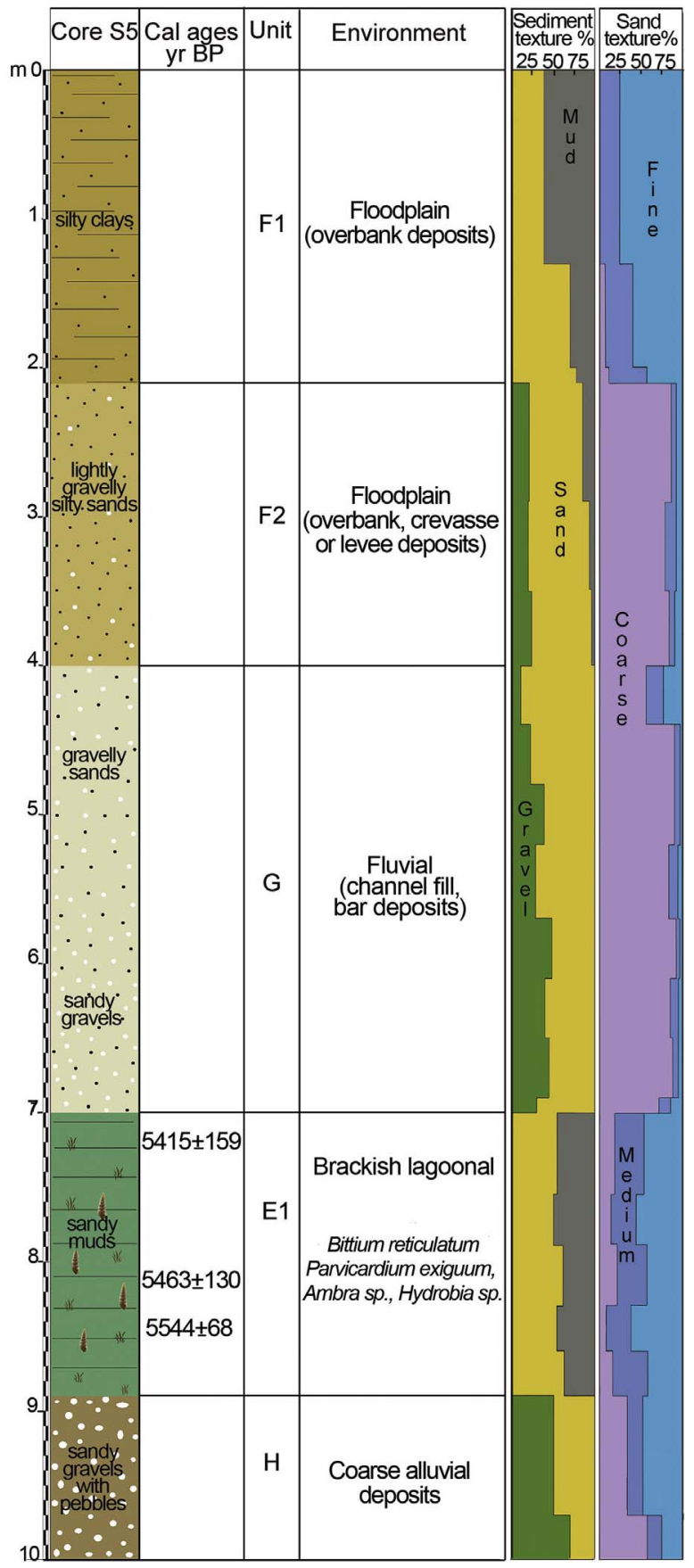

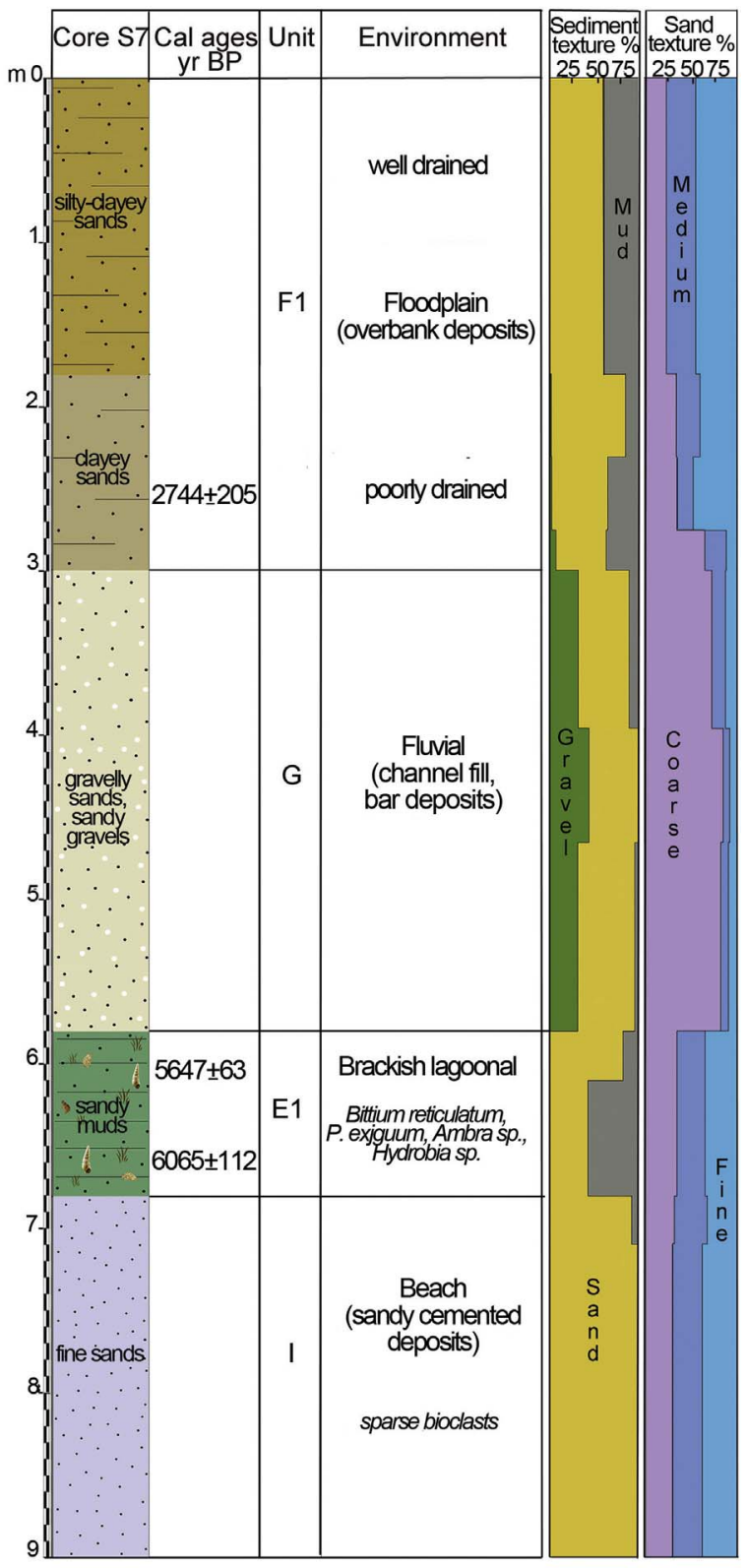

Fig. 3. Logs of S5 and S7 cores: lithostratigraphy and grain size analyses.

\subsection{2. $S 2$ to $S 7$ cores}

These cores were placed in the modern coastal plain, between the Sa Osa archaeological site and the current shoreline (Fig. 1b).

\subsubsection{Unit $H$ : alluvial plain (10.0-8.9 m, S5)}

Unit $\mathrm{H}$ is a sandy to gravelly unit found at the bottom of S5 core (Fig. 3). This unit shows light yellowish brown colour (2.5Y 6/4) with mean grain size ranging from very fine gravel to very coarse sand $(3,16 \div 1,31 \mathrm{~mm})$. The sediments are poorly to very poorly sorted with positive skewness (Supplementary Fig. S5). No shells fragments, microfossils and plant remains were found in this unit. Coarse sediments, presence of fine matrix and the lack of fossils is characteristic of the deposition of transported materials in high energy alluvial environment. The sharp contact between the $\mathrm{H}$ and $\mathrm{E}$ units indicates a stratigraphic discontinuity.
4.1.2.2. Unit I: littoral environment $(9.0-6.8 \mathrm{~m}, \mathrm{S7})$. This unit is only present at the bottom of core S7 (Fig. 3). Fine sands, partially cemented by calcium carbonate, characterize Unit I. Grains are well rounded and are mainly made of quartz and feldspar. Sparse biosclasts (unidentifiable foraminifera) were also observed. We interpret this unit as a beachrock (sensu stricto) deposited in a beach environment, most likely near to the shoreline as testified by the grain cementation typical of the land-sea interface.

4.1.2.3. Unit G: alluvial plain $(10.0-8.5 \mathrm{~m}, 6.0-4.1 \mathrm{~m}$, $\mathrm{S} 3 ; 10.0-8.7 \mathrm{~m}$, 4.60-2.10 m, S4; 7.0-4.0 m, S5; 5.1-4.4 m, S6; 5.8-3.0 m, S7)

Unit $G$ is a coarse light gray and light brownish gray sandy to gravelly unit. We found it at various depths in S3, S4, S5 and S7 cores (Figs. 3, 4, 5). Mean grain size range varies from very fine gravel to coarse sand $(2.20 \mathrm{~mm} \div 0.83 \mathrm{~mm})$, and sediments are very poorly 


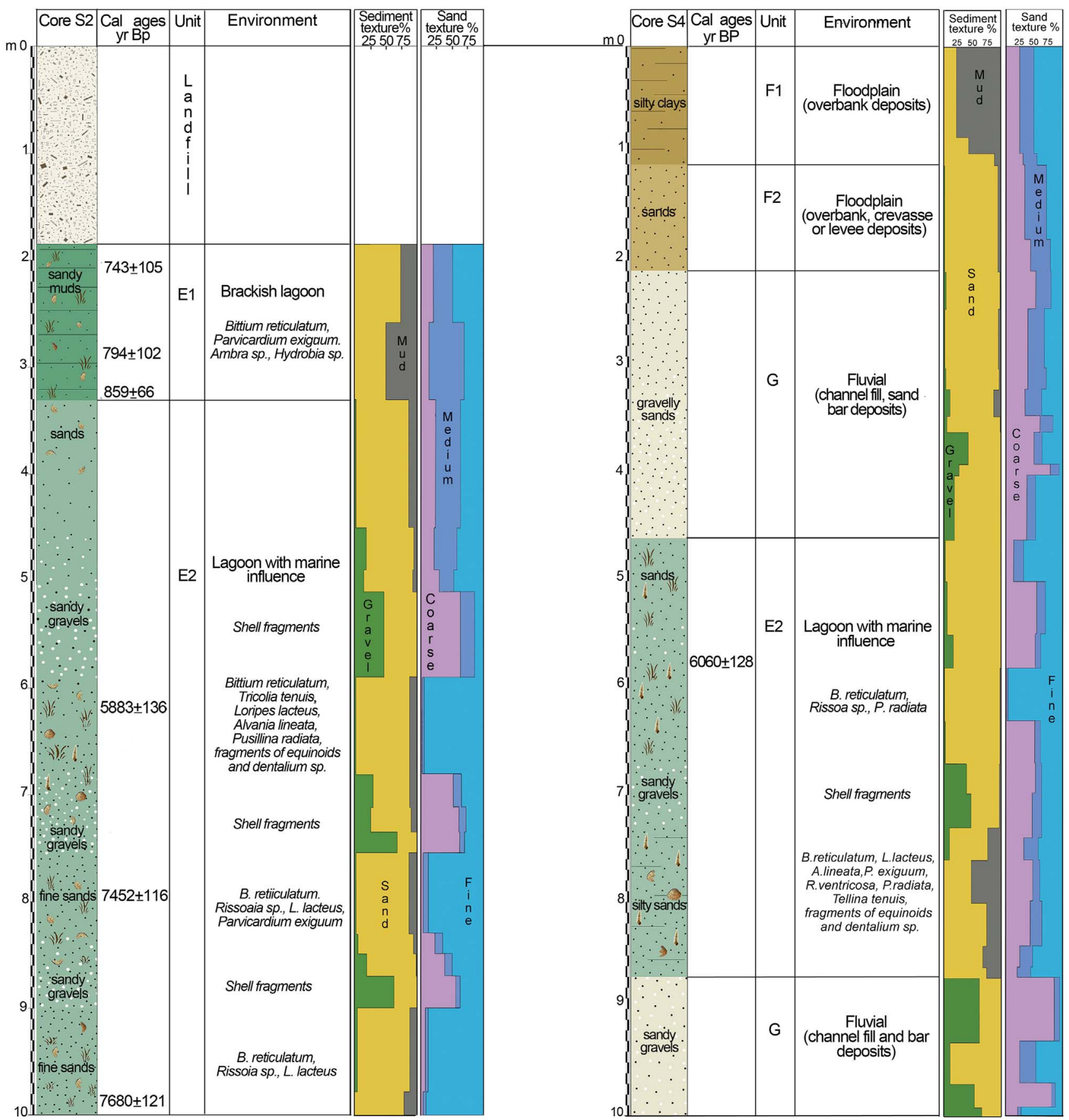

Fig. 4. Logs of S2 and S4 cores: lithostratigraphy and grain size analyses.

sorted with positive skewness (Supplementary Figs. S3, S4, S5, S6 and S7). Plant remains and shell fragments are rare or totally absent. We further observed a significant presence of quartz, feldspar and abundant lithic of metamorphic, granitic, and volcanic rocks. The grain-size and compositional characteristics of unit G, the lack of sedimentary structures (laminations or layers) and the almost total absence of shell fragments, suggest a medium to high-energy fluvial environment (most likely a channel fill or a fluvial bar).

Unit G passes gradually upward to unit F (S3, S4, S5, S7 cores), and generally overlaps on unit E (S4, S5, S6, S7 cores).

4.1.2.4. Unit E: lagoonal environment with marine and fluvial influence. Unit $\mathrm{E}$ is a muddy to sandy unit that was present in all cores. The grain size composition and the biogenic component of sediments show variability. Even if irregularly distributed, both faunal assemblages and plant remains indicate a brackish lagoonal environment with variable marine or river influence. For this reason, we subdivide this unit in three sub-units.

4.1.2.4.1. Sub-Unit E1: brackish lagoonal deposits (3.30-1.85 m, S2; 8.9-7.0 m, S5; 6.8-5.8 m, S7)

This sub-unit, found in S2, S5 and S7 cores (Figs. 3, 4) (Supplementary Figs. S2, S5 and S7), consists in very dark gray (2.5Y 3/1) sandy mud with plant and wood fragments and remains of bivalve and gastropod shells. The transition with the underlying units is sharp in S5 and S7 core. Dominant molluscan species (Supplementary Table C) are the $B$. reticulatum (infralittoral sands) and Pavicardium exiguum (lagoonal). Secondary species include Abra sp. and Hydrobia sp. (lagoonal). Microfossil analysis (Supplementary Table D) indicates that foraminifera assemblages are dominated by Ammonia. tepida and $Q$. seminula (marine and paralic species) while ostracofauna is mainly 

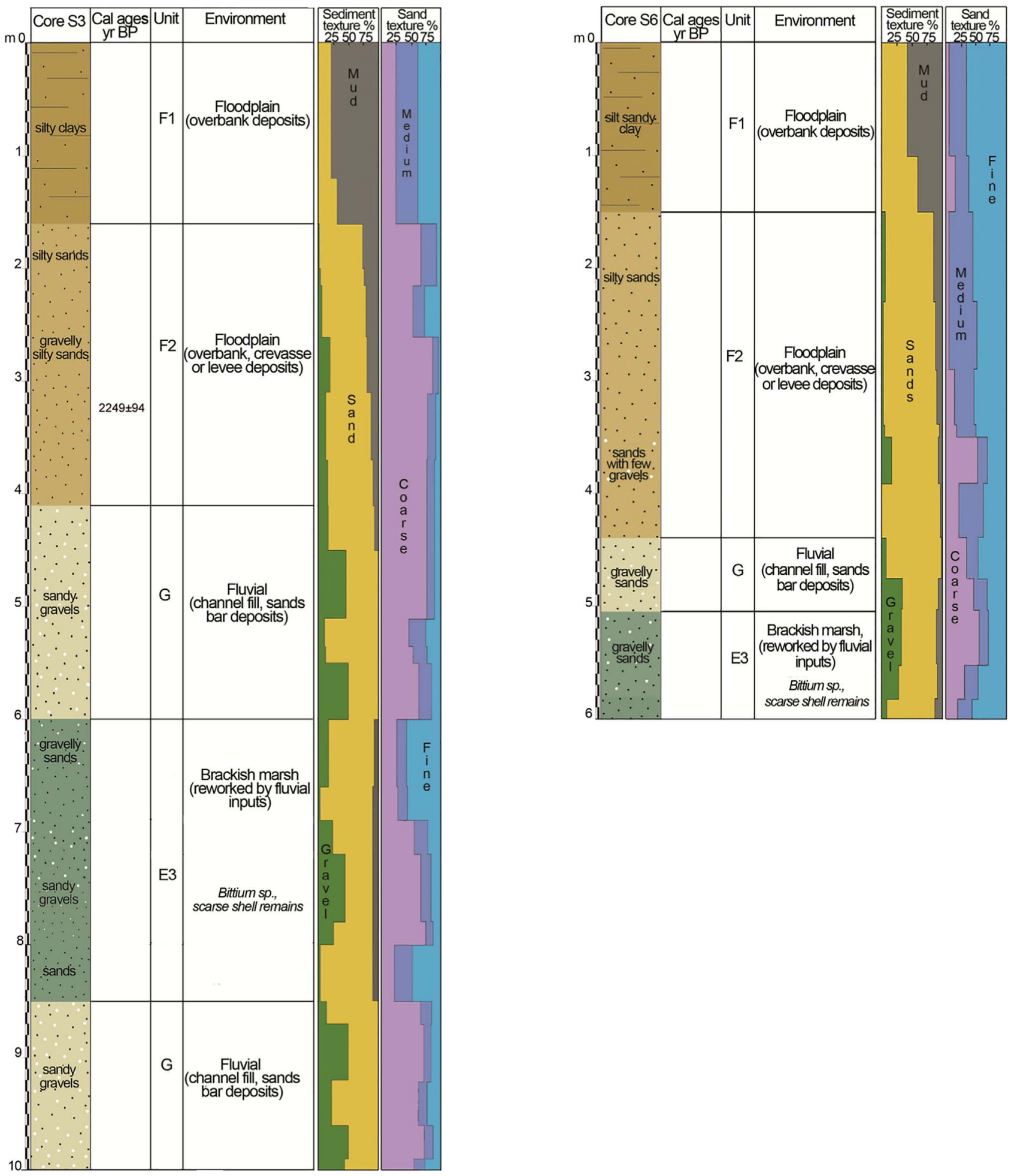

Fig. 5. Logs of S3 and S6 cores: lithostratigraphy and grain size analyses.

composed by brackish littoral species (Cyprideis torosa and rare Loxochonca elliptica). The fine-grained sedimentology and the faunal assemblages evoke a brackish lagoonal environment with intermittent connection to the open sea.

Six ${ }^{14} \mathrm{C}$ dates constrain the age of this sub-unit between ca. 0.6 and 0.9 cal. ka BP in S2 core, between ca. 5.2 to 5.6 cal. ka BP in S5 core and from ca. 5.4 to 6.0 cal. ka BP in S7 core.

4.1.2.4.2. Sub-unit E2: backshore lagoonal deposits (10.0-3.3 m, S2; 8.7-4.6 m, S4)
This sub unit is mainly characterized by gray (Gley $15 / \mathrm{N}$ ) and dark gray (Gley $14 / \mathrm{N}$ ) silty sands alternated with layers of coarser sands (Fig. 4) (Supplementary Figs. S2 and S4). Molluscan species are abundant (Supplementary Table C). They are dominated by marine (B. reticulatum, Tellina tenuis) and lagoonal taxa as $P$. exiguum, rare $C$. glaucum, Loripes lacteus while secondary species are Rissoa ventricosa, Hydrobia sp., Abra sp. Broken pieces of echinoids and scaphopods (Dentalium sp.) were also observed. Microfaunal assemblages (Supplementary Table D) are mainly represented by benthic foraminifera 
(Ammonia sp., Quinqueloculina sp., Elphidium sp.) and poorly preserved valves of ostracods (C. torosa and few $L$. elliptica). This sub-unit shows higher species diversity compared to the E1 attesting the increase of marine influence in the lagoonal environment. We interpreted the presence of coarser layers found within this lagoonal sub-unit as storm washover deposits in the backshore lagoon. Two ${ }^{14} \mathrm{C}$ dates constrain the age of this sub-unit from ca. $7.7 \mathrm{cal}$ ka BP in S2 core and ca. 6.0 cal. ka BP in S4 core.

4.1.2.4.3. Sub-unit E3: brackish lagoonal deposits with fluvial inputs (8.50-6.0 m, S3; 6.0-5.1 m, S6)

This sub-unit, found in S3 and S6 cores (Fig. 5), shows a large grain size variability ranging from gray $(2.5 \mathrm{Y} 6 / 1)$ sandy gravels to silty sands. Sediments show a chaotic pattern, they are very poorly sorted and with skewness varying from positive to negative (Supplementary Figs. S3 and S6). Shell remains are scarce and mostly fragmented. We only observed presence of small Bittium sp. associated to unidentifiable plant remains. Foraminifera and ostracods are mostly scattered, reworked and broken. The only species identifiable are Ammonia tepida, Ammonia. parkinsoniana, C. torosa (Supplementary Table D) with rare freshwater ostracod (Candona spp.). This is generally indicative of an oligohaline environment, such as a brackish marsh. However, the lack of a robust faunal assemblage suggests that the depositional environment of this sub-unit was probably a brackish water-body influenced by fluvial inputs.

\subsubsection{Unit F: floodplain environment}

The Unit F is at the top of the stratigraphic record of S3, S4, S5, S6, S7 cores (Figs. 3, 4, 5). This unit lacks in faunal assemblages and only unidentifiable plant remains were found. We generally interpret this unit as floodplain deposits. The silty clay and sandy sediments represents typical deposits of areas inundated by flood events. However, the variability of the sedimentological parameters allowed defining two subunits (Supplementary Figs. S3, S4, S5, S6 and S7):

4.1.2.5.1. Sub-unit F2: overbank including crevasse and levee deposits (4.1-1.6 m, S3; 2.1-1.1 m, S4; 4.0-2.1 m, S5; 4.4-1.5 m, S6). This subunit mainly consists of medium-coarse pale brown (10YR 6/3) sands that gradually decrease upwards to light yellowish brown (2.5Y 6/4) medium-fine silty sands. Sorting ranges between poorly and moderately well sorted, whereas skewness is variable according to the content of fine matrix or some gravels. We interpreted this subunit as result of an overbank deposition, including crevasse or levee sands deposits in the lower part of this unit. One ${ }^{14} \mathrm{C}$ date yielded an age of ca. $2.2 \mathrm{cal}$. ka BP at $3.25 \mathrm{~m}$ core depth in S3.

4.1.2.5.2. Sub-unit F1: fine overbank deposits $(1.6-0 \mathrm{~m}, \mathrm{S3} ; 1.1-0 \mathrm{~m}$, S4; 2.1-0 m, S5; 1.5-0 m, S6; 3.0-0.0 m, S7). This sub-unit is composed of silty-clay sands gradually passing upward to silty clay or clay sandy. The grain size analysis shows sediments with texture from sandy loam to clay loam upwards; the thickness is 1.1 to $3.0 \mathrm{~m}$ and the colour varies from dark grayish brown (10YR 4/2) to light olive brown (2.5Y 5/ 3 ), with the exception of dark gray (10YR 4/1) muddy sands sediments at $1.8-3.0 \mathrm{~m}$ core depth in S7. Along this unit we found few plant remains in the silty-clay layers. We interpret this sub-unit as the result of an overbank deposition, corresponding to well drained floodplain deposits, except for the dark gray sediments in S7, probably related to poorly drained conditions or to the formation of a small swamp in the alluvial plain. The overall succession, in all cores, shows a characteristic fining-upward trend. One ${ }^{14} \mathrm{C}$ date yielded an age for this sub-unit of ca. 2.8 cal. ka BP at $2.6 \mathrm{~m}$ core depth in S7.

\subsection{Pollen analysis}

Pollen analysis was successfully performed on 19 out of 21 samples. The results are presented in Fig. 6. Each pollen diagram includes: a percentage pollen record of selected taxa, the Arboreal Pollen (AP)/Non Arboreal Pollen (NAP) percentage diagram and the total pollen concentration. Pollen preservation was generally good, since the number of indeterminable grains (degraded, corroded and broken) exceed $5 \%$ only in two samples ( $7.6 \mathrm{~m}$ in core $\mathrm{S} 5$ and $3.6 \mathrm{~m}$ in core $\mathrm{S} 2$ ). The total pollen concentration varies between 1000 and 83,000 terrestrial pollen grains $/ g$. On the whole, 54 taxa were identified; they contribute to define both the vegetation characteristics and the aquatic environmental conditions of the Tirso river coastal plain at different time intervals.

The pollen record from core S7 (6.78-6 m; ca. 6.0-5.6 cal. ka BP) is composed of 8 samples. High frequencies of Alnus (27\%) suggest that the Tirso river floodplain was covered by riparian forest formations.

The coastal Alnus-dominated forests are of two main types, the floodplain forests and the alder carrs. Floodplain forests, excluding those covering the seepage sites, are only periodically flooded woodlands. Their canopies are characterized by the dominance of hardwood tree species, above all alders (Alnus glutinosa, A. incana), ashes (Fraxinus angustifolia, F. excelsior), elms (Ulmus laevis, U. minor), poplars (Populus alba, P. nigra), oak (Quercus robur) and willows (Salix spp.) (Brullo and Spampinato, 1999; Douda et al., 2015). Alder carrs, instead, represent almost monospecific forest stands of Alnus glutinosa, occurring at strongly and permanently waterlogged sites such as lakes, swamps and waterlogged depressions in floodplains. In large river floodplains, both floodplain forests and alder carrs can occur next to each other, forming temporally variable habitat mosaics (Jurko, 1958). Currently, the ranges of these extremely vulnerable woods are very fragmented and reduced in size, being confined in narrow stands behind the dunes and in the interdunal wet environments, but in the past they had a much wider distribution. Especially between 6.0 and $5.0 \mathrm{cal}$. ka BP, the coastal regions of estuarine sites document the development of Alnusdominated forest formations in the central Mediterranean region (Di Rita et al., 2010). This vegetation pattern is the results of more complex environmental dynamics triggered by a decrease in the rate of sea level rise that determined deep geomorphic and sedimentological changes in the river floodplains, consistent with coastal barrier accumulation, lagoon habitat formations, river mouth modifications, and peat deposition among others (Di Rita et al., 2015). The regional woodlands were mostly composed of evergreen Quercus forests and Ericaceae scrublands, rich in other evergreen elements such as Quercus suber, Olea, Pistacia and Arbutus, as also documented in other coastal sites of Sardinia and Corsica at that time (Reille, 1992; Beffa et al., 2016; Currás et al., 2017; Poher et al., 2017). Significant frequencies of Chenopodiaceae (9\%), accompanied by occurrences of foraminiferal linings and dinocysts, suggest the local presence of a salt-marsh environment, whose development was influenced by sea water input into the sedimentary basin, as also reported in many other coastal sites in the central Mediterranean region (Bellotti et al., 2011; Di Rita, 2013; Di Rita and Melis, 2013; Poher et al., 2017). The human impact is documented by the record of cereal type pollen, possibly revealing cultivation activities. The record of Olea and Vitis, between ca. 6.0 and 5.6 cal. ka BP, seems more related to the presence of natural populations than to exploitation by humans, although they have represented important economic plants in the history of the Tirso river coastal region.

The pollen record from core S5 (ca. 8.2-7.2 m; 5.4 cal. ka BP) is composed of 5 samples. The AP values, varying between ca. $55 \%$ and $70 \%$, indicate a semi-forested landscape. This was still locally dominated by riparian Alnus formations. The contemporary record of Chenopodiaceae, foraminiferal linings and cysts of dinoflagellates (dinocysts) still point to the presence of brackish/saline aquatic environment covered by halophilic vegetation communities. In particular, the increased frequencies in Chenopodiaceae (16\%), with respect to the preceding time-interval, suggest a further spread of salt-marsh vegetation onto the floodplain. The main evidence of human impact is here represented by scattered pollen grains of cereal type as possible evidence of cultivation in the region.

The pollen record from core S2 (ca. 3.6-2.0 m; ca. 0.910.74 cal. ka BP) is composed of 6 samples. It documents a landscape dominated by herbaceous vegetation. The particularly high frequencies 

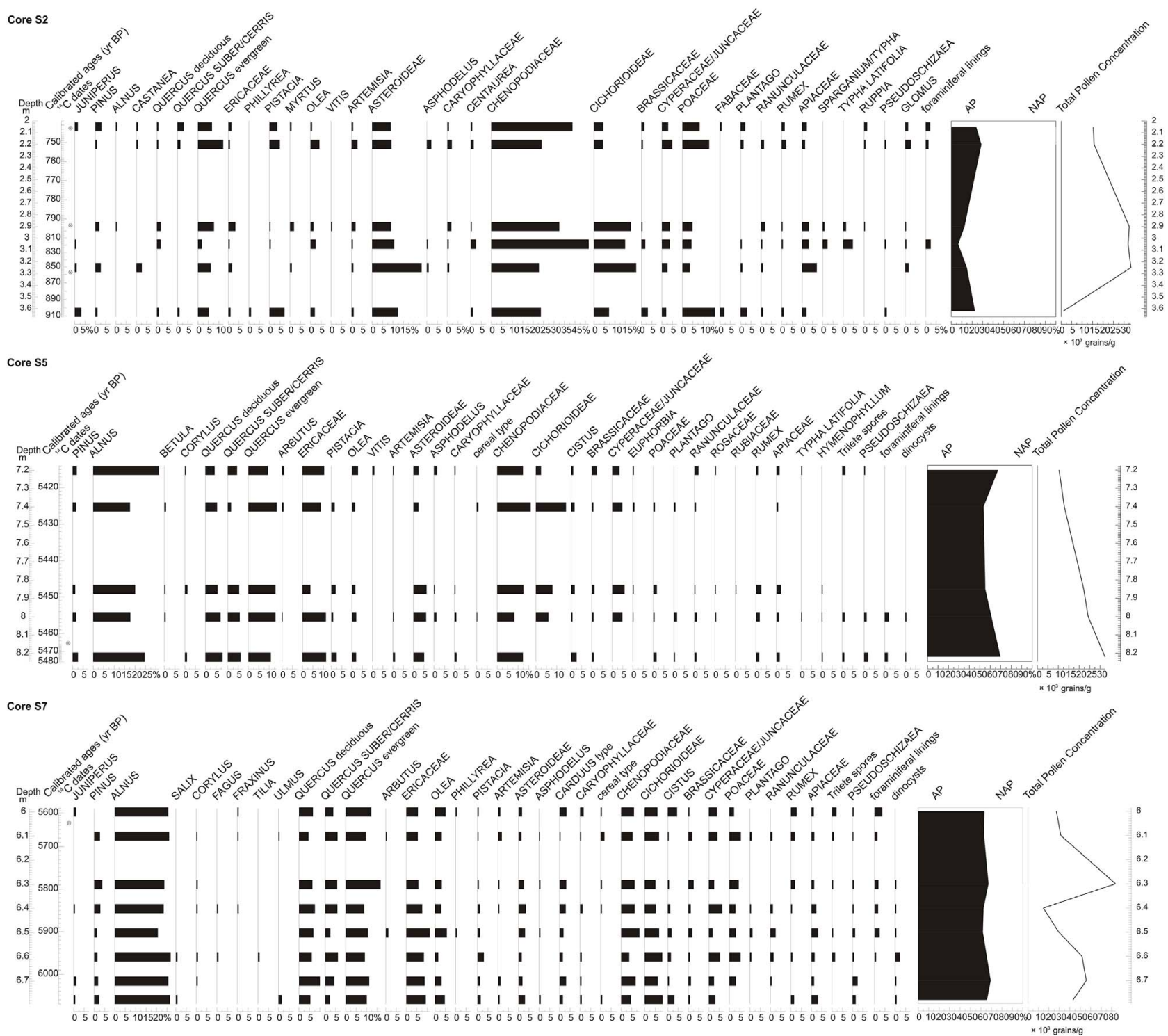

Fig. 6. Pollen percentage diagram of selected taxa from the S2, S5 and S7 cores.

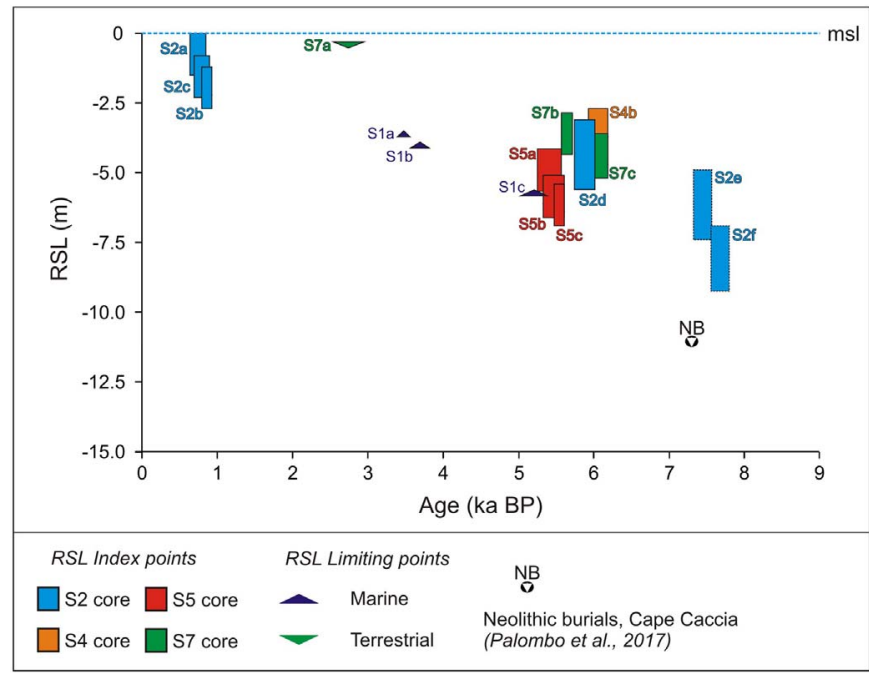

Fig. 7. RSL reconstructions in the Tirso coastal plain. Index points (boxes) are plotted as calibrated age against change in sea level relative to present. Limiting points are plotted as terrestrial or marine horizontal lines. Dimensions of boxes and lines for each point based on $2 \mathrm{~s}$ elevation and age errors. of Chenopodiaceae (46\%), accompanied by occurrences of Ruppia and foraminiferal linings, suggest that the main vegetation element of the Tirso coastal plain was represented by a particularly vast salt-marsh. Cyperaceae/Juncaceae, Poaceae and Typha point to reeds and sedges communities that also formed the marshy vegetation. Asteraceae, both Asteroideae and Cichorioideae, Apiaceae, Plantago and Brassicaceae were other floristic components of this patchy open vegetation environment. The few natural woody stands were mostly composed of evergreen taxa, such as evergreen Quercus, Pistacia and Ericaceae. Conversely, Olea was probably cultivated during the Middle Ages. The records of Vitis and Castanea represent another evidence of human impact. However, while the record of Vitis may reflect local agricultural practices, Castanea seems more related to regional and extra-regional cultivations. Surprisingly, the pollen sequence of core S2 does not record any cereal pollen, possibly because the combination of marshy environment and salty soils discouraged the local development of cereal fields.

\subsection{Relative sea-level datapoints}

Facies analysis allowed the production of a new set of 12 RSL index points as well as 1 terrestrial and 3 marine RSL limiting points 
(Table 1). The totality of index points derived from lagoonal samples and gave insights into the RSL evolution between ca. 7.6 and 5.5 cal. ka BP (mid-Holocene). The remaining part of the Holocene is only constrained by limiting points and by 3 lagoonal index points (Fig. 7).

We associated an indicative range typical of open lagoon to the samples dated in the subunit $\mathrm{E}_{2}$ and an indicative meaning typical of brackish semi-enclosed lagoon, to all the samples dated in the subunit $\mathrm{E}_{1}$ (see Section 3.4). We further transform in marine limiting points samples dated in Unit A (shallow littoral environment) and in terrestrial limiting point the sample dated in subunit $\mathrm{F}_{2}$ (fluvial overbank deposition).

\section{Discussions}

\subsection{Mid to late Holocene landscape evolution of Tirso coastal plain}

Biostratigraphical and pollen data coupled by the ${ }^{14} \mathrm{C}$ ages of the samples extracted from the 7 cores provide novel information on the mid to late Holocene landscape evolution of the Tirso coastal plain. However, due to the dating uncertainty of the two oldest dates (see Section 5.2), we discuss here only the modification occurring in the last ca. 6.0 cal. ka BP.

Our stratigraphic data testify the constant interplay between littoral and fluvial processes in controlling the environmental evolution of the area. The sole exception is recorded in S1 core (in the modern backshore) where littoral processes are the major driver of the environmental changes.

Between ca. 6.0 and $5.5 \mathrm{cal}$. ka BP the Tirso coastal plain was occupied by a coastal lagoon connected with the open sea and most likely subject to frequent storm-related inundation as testified by the marine sands and gravel interbedded with the lagoonal deposits (Fig. 8). This is in agreement with the mid-Holocene increase in the storm activity recorded in NW Mediterranean (Sabatier et al., 2012). Faunal assemblages of Subunit E2 clearly indicate the concomitant presence of open marine and lagoonal species typical of a calm environment with a substrate of muddy sands (Pérès and Picard, 1964; Carboni et al., 2010). The foraminifera associations suggest shallow marine to paralic environments, with some species tolerant to conditions of variable salinity (Rossi et al., 2011). The age of sub-unit E2 in S4 core (located ca. 900 m northwest of S2 core; Fig. 4) corroborates the hypothesis that sea reached its maximal landward influence at ca. 6.0 cal. ka BP. Saltwater influence is also evident in the landward portion of the Tirso coastal plain (S3, S5, S6, S7 cores). Notably, the faunal and pollen evidence retrieved from a dark gray sandy mud (sub-unit E1) indicate that between ca. 6.0 and $5.5 \mathrm{cal}$. ka BP the whole area was characterized by shallow brackish lagoons and salt-marshes, which extended up to a maximum of $2 \mathrm{~km}$ inland from the modern shoreline (Fig. 8). On the other hand, microfossils assemblages of sub-unit E1, characterized by reworked individuals of benthic foraminifera and poorly preserved valves of euryhaline ostracods, are consistent with a brackish-water depositional environments subject to salinity changes (Bellotti et al., 1994; Murray, 2006; Frezza and Carboni, 2009). This environmental reconstruction is consistent with the pollen records of both S7 and S5 cores that document an aquatic environment strongly influenced by the input of sea-water, as reflected by the significant amounts of salt-tolerant chenopods and the occurrence of both foraminiferal linings and dinocysts. At the same time, the high frequencies of Alnus (>33\%) indicate that the Tirso plain was also covered by riparian forest formations presumably related to the presence of semi-permanent freshwater ponds, likely formed by complex geomorphological and sedimentological processes at the Tirso river mouth. The development of Alnus-dominated forest formations (both of floodplain forests and alder carrs) between ca. 6.0 and $5.0 \mathrm{cal}$. ka BP is a common vegetation feature to other coastal and estuarine regions of the Central and Western Mediterranean (Di Rita et al., 2010; Curràs et al., 2017; Ghilardi et al., 2017).

In the same period a shallow marine environment was present near the shoreline (S1 core, Unit A). Since ca. 5.5 cal. ka BP (Final Neolithic period) stratigraphical data (S1 core) indicate a seaward migration of the least $300 \mathrm{~m}$ from the present day shoreline, when the area was most likely a protected marine bay.

Between ca. 5.4 and $2.1 \mathrm{cal}$. ka BP a continuous overbank sediment deposition developed in most of the study area (Fig. 8), while near the shoreline a progressive evolution from a shallow marine environment into a beach environment (Unit B, S1 core) occurred between ca. 3.6 and 3.4 cal. ka BP (Middle Bronze Age). Fluvial sedimentation became dominant from mid- to late-Holocene (i.e. last $5.5 \mathrm{cal}$. ka), as indicated by the development of fluvial and overbank deposits (Unit $\mathrm{G}$ and Unit F), according to stratigraphic data of S3, S4, S5, S6 and S7 cores. The upward transition from fluvial deposits (Unit $\mathrm{G}$ ) to floodplain deposits (Unit F) documents the formation of an alluvial depositional system from the Final Bronze Age (ca. 2.9 to 2.7 cal. ka BP). Changes in the fluvial dynamics are testified by the sedimentological characteristics of the unit $\mathrm{F}$ that evokes low-energy alluvial deposition, typical of a floodplain occasionally affected by river floods.

Between ca. 2.2 and $0.7 \mathrm{cal}$. ka. BP the landscape of the Tirso coastal plain was characterized by backshore dunes (Unit C, S1 core) that most likely isolated the back-coastal areas and promoted the formation of wetlands environments (shallow brackish water environments or marsh areas) as documented by the sub-unit E1 in S2 core.

\subsection{Relative Sea-level evolution}

The new dataset of ${ }^{14} \mathrm{C}$ data provides new insights on the RSL evolution in this sector of western Sardinia. Submerged archaeological structures (Roman quarry and Phoenicians tombs) near Tharros (Fig. 1a), provided evidence that the total RSL changes was $>1 \mathrm{~m}$ since
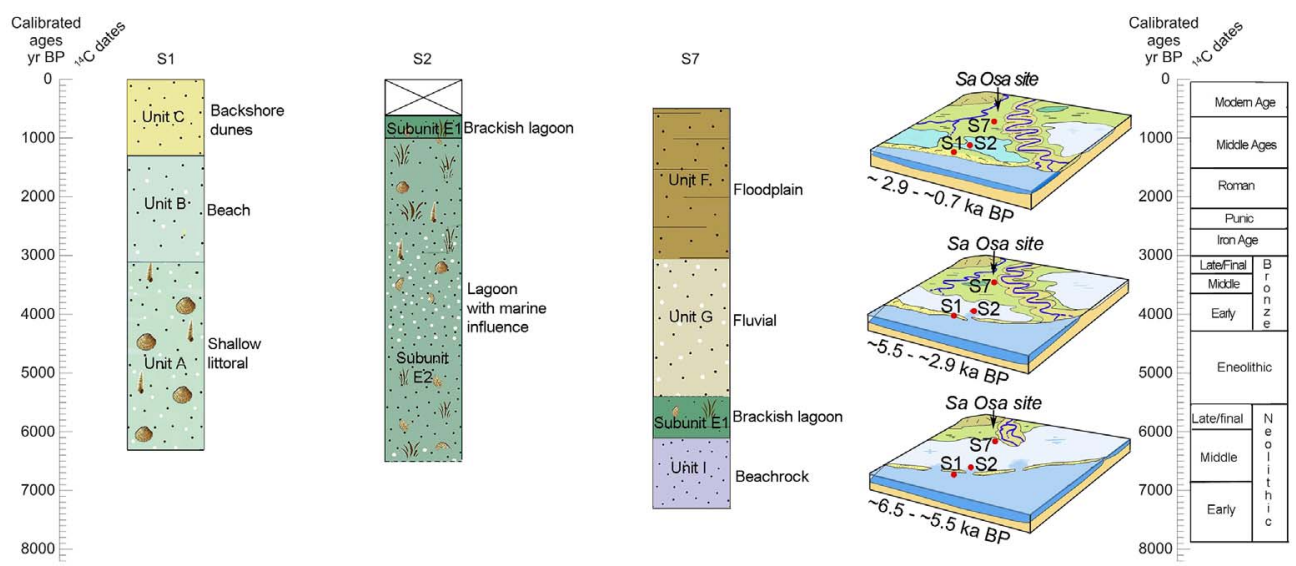

Fig. 8. Environmental evolution of the Tirso coastal plain as reconstructed by facies analysis and interpretation. In the left side, the lithostratigraphy of the most representative cores of this study, namely S1, S2, and S7 cores, is plotted against age (cal. ka BP). The Age-depth models of each core are based on the linear interpolation among calibrated dates (see Table 1). In the right side, we propose a schematic reconstruction of the main phases of the Tirso coastal plain evolution. 
ca. 2.3 cal. ka BP and $>0.79$ since ca. 2.0 cal. ka BP (Antonioli et al., 2007; Lambeck et al., 2011). A sample extracted from a core performed in Mistras lagoon placed the RSL above $-3.2 \mathrm{~m}$ at ca. $4.6 \mathrm{cal}$. ka (Di Rita and Melis, 2013). More recently, lagoonal facies found in off-shore cores in the Gulf of Oristano revealed ca. $28 \mathrm{~m}$ of RSL changes in the last ca.9.4 cal. ka BP (De Falco et al., 2015). Thus, our record significantly improved the RSL record in the area providing new insights into the RSL changes, notably in the mid-Holocene (8.0-4.0 cal. ka BP). In Fig. 7 we plotted the RSL index and limiting points derived from the new cores performed in the Tirso coastal plain. Oldest index points indicate RSL was at $-8.0 \pm 1.25 \mathrm{~m}$ at ca. $7.7 \mathrm{cal}$. ka BP (S2f) (Table 1 ) and above $-6.2 \pm 1.25 \mathrm{~m}$ at ca. $7.4 \mathrm{cal}$. ka BP (S2e). These data seem to conflict with RSL position suggested by early Neolithic burials found in a marine cave in Capo Caccia (NW Sardinia, ca. $80 \mathrm{~km}$ northwards the Tirso coastal plain, Lambeck et al., 2004; Palombo et al., 2017). The current position of these burials and the dating of the associated pottery constrain the RSL position below ca. $-11 \mathrm{~m}$ at ca. 7.3 cal. ka BP (Palombo et al., 2017). Post-depositional uplift can difficulty account for this misfit, being this area considered tectonically stable since the last interglacial (i.e. last ca. 125 cal. ka BP, Ferranti et al., 2006). For this reason, caution should be used in the assessment of the RSL position indicated by the two oldest samples of our dataset. At the moment, we cannot exclude aging effects in this lagoonal sequence, resulting in apparent older age of these samples (Table 1). Additional coring in adjacent areas revealed lagoonal sequences at similar depths. Further ${ }^{14} \mathrm{C}$ dating of both lagoonal shells and organic matter (currently on-going) could provide additional insights into the RSL position between 8.0 and 7.0. In our opinion, compaction may have a major role in controlling their current elevation. In fact, ca. $7 \mathrm{~m}$ of alluvial sediments overlays these three ${ }^{14} \mathrm{C}$ dates (subunit E1, S5 core, (Fig. 3). For this reason, we do not think that RSL index points from S5 core are indicative of the RSL evolution of the area. This is further confirmed by a marine limiting point placing the RSL above $-5.7 \mathrm{~m}$ at ca. 5.3 cal. ka BP (S1c, Table 1). Our data poorly constrain the remaining part of the Holocene. Two marine limiting points (S1b and S1a) placed the RSL above $-4 \mathrm{~m}$ at ca. $3.7 \mathrm{cal}$. ka BP and above $-3.6 \mathrm{~m}$ at ca. $3.5 \mathrm{cal}$. ka BP, respectively. At ca. $2.2 \mathrm{cal}$. ka BP, one terrestrial limiting point (S7a) constrains the RSL below $-0.4 \mathrm{~m}$. The three youngest index points show scatter (Fig. 7). The highest (most likely less affected by compaction) indicate RSL rose by $0.5 \pm 0.7$ in the last ca. 0.7 cal. ka BP.

\subsection{Environmental control on the settlements of the Tirso coastal plain}

The portion of the Gulf of Oristano comprised between the Sinis Peninsula and the S. Giusta lagoon was densely settled since the Neolithic period (Depalmas and Melis, 2010). However, there is a clear disparity in the concentration of settlements between the rocky Sinis peninsula and the Tirso coastal plain (Fig. 1a). Our results provided evidence that such difference in the density of settlements was strongly influenced by the major environmental changes of the Tirso coastal plain, especially in the last five millennia. We robustly documented the end of the transgressive trend at ca. 6.0-5.5 cal. ka BP, consistent with the significant slow of sea-level rising rates recorded along the Mediterranean coasts (e.g., Anthony et al., 2014; Maselli and Trincardi, 2013; Amorosi et al., 2017). As a result, during the Eneolithic (ca. 5.5 to $4.2 \mathrm{cal}$. ka BP) and Bronze age (ca. 4.2 to $2.9 \mathrm{cal}$. ka BP) the fluvial activity dramatically increased. It triggered intense lateral and vertical sedimentation linked to river channel migration, as documented by accumulation of coarse-grained sand bodies on the lagoon deposits. Afterward, a progradational trend started, causing the seaward migration of the shoreline and, consequently, of the barrier-lagoon system.

Due to the discontinuity of our pollen record, we cannot establish whether human activities exerted an indirect influence on the sedimentological processes enhancement through clearance and exploitation of the local forest cover. The pollen diagrams record two distinct temporary phases, from ca. 6.1 to 5.4 cal. ka BP (cores S7 and S5), and from ca. 0.91 to 0.74 cal. ka BP (core S2), respectively, suggesting that the Tirso coastal plain experienced a strong reduction of the forest vegetation. However, there is no information about the local forest dynamics in between these two phases, especially during the Eneolithic and Bronze Age. In western Sardinia, the available palynological records (Di Rita and Melis, 2013; Buosi et al., 2015) and palaeobotanical data (Bakels, 2002; Sabato et al., 2015; Ucchesu et al., 2015), considered altogether, indicate that during the Eneolithic and Bronze Age the impact of agricultural practices was directed towards an already semi-open landscape, and did not produce any further deforestation process (Di Rita and Melis, 2013). During the Eneolithic and Bronze Age, the pollen record from Mistras Lagoon, ca. $6 \mathrm{~km}$ far from Tirso coastal plain, shows a semi-open landscape, characterized by a patch of Mediterranean maquis and salt-marsh vegetation communities. During the Nuragic phase (until ca. $2.3 \mathrm{cal}$. ka BP), the pollen evidence of agricultural activities suggests a prevailing arable farming economy, mostly based on Vitis and cereal exploitation, subsequently replaced by a prevailing stock rearing economy. Despite this intense human impact, further documented by an increase of fire activity during the Nuragic phase, no clear forest decline is recorded in the pollen diagram of Mistras. Similarly, at Sa Curcurica, on the other side of Sardinia, during the Eneolithic and Bronze Age the pollen evidence of agricultural activities was associated to a phase of marked stability in the forest cover, especially between ca. 5.3 and 3.5 cal. ka BP (Beffa et al., 2016).

This scenario contrasts with the landscape evolution of the Tirso coastal plain, where a rapid and continuous environmental modification during the last ca. $6.0 \mathrm{cal}$. ka BP did not assure suitable conditions for the establishment of stable settlements; thus, this may explain the low density of historical and prehistorical archaeological remains in this area, especially if compared to the rocky area of Sinis peninsula (Fig. 1a). However, we cannot exclude that the building technique may also explain this scarcity of finds. In fact, the structural characteristics observed during the Sa-Osa archaeological excavations revealed the sole presence of negative structures without raised stone, which are very difficult to preserve (Usai et al., 2012).

In the Bronze Age village of Sa Osa, interesting aspects both of strong exploitation of local resources (river and sea fishing, farming of pigs and cattle, hunting deer) and specialized production (e.g., viticulture, pottery, industry of bone) were recently described (Usai et al., 2012; Sabato et al., 2015; Ucchesu et al., 2015). They indicate the strong man-environment interaction and the possibility of adaptation of the communities of the Bronze Age in critical climatic-environmental conditions, characterized by instability. Such abundance of resources may have attracted other settlements both in the floodplain and on the border of the former coastal lagoons. These hypothetic settlements may be now no longer visible because covered by river sediments. However, none of our cores revealed traces of archaeological remains and further coring campaigns are necessary to confirm or not the above-mentioned hypothesis.

\section{Conclusions}

A multidisciplinary analysis including sedimentology, faunal assemblages, pollen data and radiocarbon dating allowed reconstructing the palaeoenvironmental evolution of the largest coastal plain of Sardinia during the last ca. $6.0 \mathrm{cal}$. ka BP. We robustly demonstrated that for most of the mid-Holocene, a large portion of the Tirso coastal plain was occupied by a coastal lagoon connected with the open sea and with frequent storm-related marine inundation. After the maximal sea transgression, recorded at ca. $6.0 \mathrm{cal}$. ka BP, the river activity became the predominant factor in controlling the landscape evolution in the Tirso coastal plain. It triggered a seaward migration of the shoreline of at least $300 \mathrm{~m}$ since the Final Neolitic period (ca. 5.5 cal. ka BP). Further, fluvial sediments rapidly filled the shallow lagoons and marshes and successively a continuous overbank sediment deposition 
occurred in most of the study area until Punic-Roman period (ca. 2.1 cal. ka BP). Such major landscape modification recorded in the Tirso coastal plain seems to have had a key role in the pattern of historical and prehistorical settlements of this wide portion of western Sardinian coastline.

Furthermore, we outlined two distinct temporary phases in the vegetational evolution of the Tirso coastal plain. The first (from ca. 6.1 to $5.4 \mathrm{cal}$. ka BP) showing a semi-forested landscape dominated by an admixture of local vegetation formations of saltmarsh and riparian forest, and regional evergreen woodlands. The second (between ca. 0.9 and $0.7 \mathrm{cal}$. ka BP) showing an open landscape characterized by a widespread chenopod-dominated saltmarsh. These data are crucial to define the past vegetation dynamics in Sardinia, especially if considering the scarcity of natural sedimentary basins suitable for pollen analysis in this island. Finally, we provide new insights on the RSL evolution in this sector of the Mediterranean. Notably, we improved the RSL record in Sardinia between 6.0 and 5.0 ka BP where only scarce data were previously available.

Supplementary data to this article can be found online at http://dx. doi.org/10.1016/j.gloplacha.2017.06.001.

\section{Acknowledgments}

Thanks are due to the "Soprintendenza Archeologia, Belle Arti $e$ Paesaggio per la città metropolitana di Cagliari e per le province di Oristano, Medio Campidano, Carbonia-Iglesias, Ogliastra" for the support in the coring activity. This work has been carried out thanks to the support of the LR/7 2010 Regione Sardegna project (CRP-27178 Il rapporto uomoambiente nella Sardegna centro-occidentale durante l'Olocene: sfruttamento delle risorse, produttività e impatto antropico). MV contributes to the LABEX ARCHIMEDE funded by the ANR through the program "Investissement d'Avenir" ANR-11-LABX-0032-01. MV further acknowledges MOPP-Medflood (INQUA CMP project 1603P) working groups for useful discussions. We also thank Donatella Magri for her precious comments.

\section{References}

Amorosi, A., Bini, M., Giacomelli, S., Pappalardo, M., Ribecai, C., Rossi, V., Sammartino, I., Sarti, G., 2013. Middle to late Holocene environmental evolution of the Pisa coastal plain (Tuscany, Italy) and early human settlements. Quat. Int. 303, 93-106.

Amorosi, A., Bruno, L., Campo, B., Morelli, A., Rossi, V., Scarponi, D., Hong, W., Bohacs, K.M., Drexler, T.M., 2017. Global sea-level control on local parasequence architecture from the Holocene record of the Po Plain, Italy. Mar. Pet. Geol.

Anthony, E.J., Marriner, N., Morhange, C., 2014. Human influence and the changing geomorphology of Mediterranean deltas and coasts over the last 6000 years: from progradation to destruction phase? Earth-Sci. Rev. 139, 336-361.

Antonioli, F., Anzidei, M., Lambeck, K., Auriemma, R., Gaddi, D., Furlani, S., Orrù, P., Solinas, E., Gaspari, A., Karinja, S., Kovac, V., Surace, L., 2007. Sea-level change during the Holocene in Sardinia and in the northeastern Adriatic (central Mediterranean Sea) from archaeological and geomorphological data. Quat. Sci. Rev. $26,2463-2486$.

Antonioli, F., Anzidei, M., Amorosi, A., Presti, V.L., Mastronuzzi, G., Deiana, G., De Falco, G., Fontana, A., Fontolan, G., Lisco, S., Marsico, A., Moretti, M., Orrù, P.E., Sannino, G.M., Serpelloni, E., Vecchio, A., 2017. Sea-level rise and potential drowning of the Italian coastal plains: flooding risk scenarios for 2100. Quat. Sci. Rev. 158, 29-43.

Anzidei, M., Lambeck, K., Antonioli, F., Furlani, S., Mastronuzzi, G., Serpelloni, E., Vannucci, G., 2014. Coastal structure, sea-level changes and vertical motion of the land in the Mediterranean. Geol. Soc. Lond., Spec. Publ. 388 (1), 453-479.

Bakels, C., 2002. Plant remains from Sardinia, Italy with notes on barley and grape. Veg. Hist. Archaeobotany 11, 3-8.

Beffa, G., Pedrotta, T., Colombaroli, D., Henne, P.D., van Leeuwen, J.F.N., Süsstrunk, P., Kaltenrieder, P., Adolf, C., Vogel, H., Pasta, S., Anselmetti, F.S., Gobet, E., Tinner, W., 2016. Vegetation and fire history of coastal north-eastern Sardinia (Italy) under changing Holocene climates and land use. Veg. Hist. Archaeobotany 25, 271-289.

Bellotti, P., Chiocci, F.L., Milli, S., Tortora, P., Valeri, P., 1994. Sequence stratigraphy and depositional setting of the Tiber delta: integration of high-resolution seismics, well logs, and archeological data. J. Sediment. Res. 64, 416-432.

Bellotti, P., Calderoni, G., Di Rita, F., D'Orefice, M., D'Amico, C., Esu, D., Magri, D., Preite Martinez, M., Tortora, P., Valeri, P., 2011. The Tiber river delta plain (central Italy): coastal evolution and implications for the ancient Ostia Roman settlement. The Holocene 21, 1105-1116.

Bennett, K.D., 2009. Documentation for Psimpoll 4.27 and Pscomb 1.03. In: C Programs for Plotting Pollen Diagrams and Analysing Pollen Data. Queen's University of Belfast,
Department of Archaeology and Palaeoecology.

Beug, H.J., 2004. Leitfaden der Pollenbestimmung fur Mitteleuropa und angrenzende Gebiete. Verlag Friedrich Pfeil, Munich.

Bondì, S.F., 2000. Fenici e Punici nel Mediterraneo occidentale tra il 600 e il 500 aC. In: Bernardini, P., Spanu, P.G., Zucca, R. (Eds.), Maxe. La battaglia del Mare Sardonio. La Memoria Storica/Mythos, pp. 57-72 (Cagliari-Oristano).

Brückner, H., 2003. Delta evolution and culture-aspects of geoarchaeological research in Miletos and Priene. In: Wagner, G., Pernicka, E., Uerpmann, H. (Eds.), Troia and the Troad. Springer, Berlin Heidelberg, pp. 121-142.

Brückner, H., Müllenhoff, M., Gehrels, R., Herda, A., Knipping, M., Vött, A., 2006. From archipelago to floodplain-geographical and ecological changes in Miletus and its environs during the past six millennia (western Anatolia, Turkey). Z. Geomorphol. 142, 63-83.

Brullo, S., Spampinato, G., 1999. Syntaxonomy of hygrophilous woods of the AlnoQuercion roboris. Ann. Bot. 57, 133-146.

Buosi, C., Pittau, P., Paglietti, G., Scanu, G.G., Serra, M., Ucchesu, M., Tanda, G., 2015. A human occupation cave during the Bronze age: archaeological and palynological applications of a case study in Sardinia (western Mediterranean). Archaeometry 57 (S1), 212-231.

Buosi, C., Del Rio, M., Orrù, P., Pittau, P., Scanu, G.G., Solinas, E., 2017. Sea level changes and past vegetation in the Punic period (5th-4th century BC): Archaeological, geomorphological and palaeobotanical indicators (South Sardinia-West Mediterranean Sea). Quat. Int. 439, 141-157.

Butzer, K.W., 2005. Environmental history in the Mediterranean world: cross-disciplinary investigation of cause-and-effect for degradation and soil erosion. J. Archaeol. Sci. $32,1773-1800$.

Carboni, S., Lecca, L., 1985. Osservazioni sul Pleistocene Medio-superiore della penisoladel Sinis (Sardegna occidentale). Boll. Soc. Geol. Ital. 104, 459-477.

Carboni, M.G., Bergamin, L., Di Bella, L., Iamundo, F., Pugliese, N., 2002. Palaeoecological evidences from foraminifers and ostracods on Late Quaternary sealevel changes in the Ombrone river plain (central Tyrrhenian coast, Italy). Geobios $35,40-50$.

Carboni, M.G., Bergamin, L., Di Bella, L., Esu, D., Cerone, E.P., Antonioli, F., Verrubbi, V., 2010. Palaeoenvironmental reconstruction of late Quaternary foraminifera and molluscs from the ENEA borehole (Versilian plain, Tuscany, Italy). Quat. Res. 74 (2), 265-276.

Currás, A., Ghilardi, M., Peche-Quilichini, K., Fagel, N., Vacchi, M., Delanghe, D., Dussouillez, P., Vella, C., Bontempi, J.M., Ottaviani, J.C., 2017. Reconstructing past landscapes of the eastern plain of Corsica (NW Mediterranean) during the last 6000 years based on molluscan, sedimentological and palynological analyses. J. Archaeol. Sci. Rep. 12, 755-769.

D'Angelo, G., Gargiulo, S., 1978. Guida alle conchiglie Mediterranee. Fabbri, Milano.

De Falco, G., Antonioli, F., Fontolan, G., Lo Presti, V., Simeone, S., Tonielli, R., 2015. Early cementation and accommodation space dictate the evolution of an overstepping barrier system during the Holocene. Mar. Geol. 369, 52-66.

Del Vais, C., Depalmas, A., Fariselli, A.C., Melis, R.T., 2006. Il paesaggio costiero della Penisola del Sinis (OR) tra preistoria e storia: aspetti archeologici e ambientali. Atti del I Simposio "Il monitoraggio costiero mediterraneo. Problematiche e tecniche di misura". CNR - IBIMET, Sassari, pp. 309-322.

Depalmas, A., Melis, R.T., 2010. The Nuragic people: their settlements, economic activities and use of the land. In: Martini, P.I., Chesworth, W. (Eds.), Landscape and Societies. Selected Cases, pp. 167-186 (Stuttgard).

Di Rita, F., 2013. A possible solar pacemaker for Holocene fluctuations of a salt-marsh in southern Italy. Quat. Int. 288, 239-248.

Di Rita, F., Melis, R.T., 2013. The cultural landscape near the ancient city of Tharros (central West Sardinia): vegetation changes and human impact. J. Archaeol. Sci. 40, 4271-4282.

Di Rita, F., Celant, A., Magri, D., 2010. Holocene environmental instability in the wetland north of the Tiber delta (Rome, Italy): sea-lake-man interactions. J. Palaeolimnol. 44, 51-67.

Di Rita, F., Simone, O., Caldara, M., Gehrels, W.R., Magri, D., 2011. Holocene environmental changes in the coastal Tavoliere Plain (Apulia, southern Italy): a multiproxy approach. Palaeogeogr. Palaeocl. 310, 139-151.

Di Rita, F., Celant, A., Milli, S., Magri, D., 2015. Late glaciale early Holocene vegetation history of the Tiber delta (Rome, Italy) under the influence of climate change and sea level rise. Rev. Palaeobot. Palynol. 218, 204-216.

Doneddu, M., Trainito, E., 2005. Conchiglie del Mediterraneo. Il Castello, Cornaredo (MI).

Donnici, S., Serandrei Barbero, R., 2002. The benthic foraminiferal communities of the northern Adriatic continental shelf. Mar. Micropaleontol. 44, 93-123.

Douda, J., Boublik, K., Slezak, M., Biurrun, I., Nociar, J., Havrdova, A., Doudova, J., Aćić, S., Brisse, H., Brunet, J., Chytry, M., et al., 2015. Vegetation classification and biogeography of European floodplain forests and alder carrs. Appl. Veg. Sci. 19, $147-163$.

Ferranti, L., Antonioli, F., Mauz, B., Amorosi, A., Dai Pra, G., Mastronuzzi, G., Monaco, C., Orrù, P.E., Pappalardo, M., Radtke, U., Renda, P., Romano, P., Sansò, P., Verrubbi, V., 2006. Markers of the last interglacial sea-level high stand along the coast of Italy: tectonic implications. Quat. Int. 145, 30-54.

Fiorini, F., 2004. Benthic foraminiferal associations from Upper Quaternary deposits of southeastern Po Plain, Italy. Micropalaeontology 50, 45-58.

Fiorini, F., Vaiani, S.C., 2001. Benthic foraminifers and transgressive-regressive cycles in the Late Quaternary subsurface sediments of the Po Plain near Ravenna (Northern Italy). Boll. Soc. Paleontol. Ital. 40, 357-403.

Fontana, A., Vinci, G., Tasca, G., Mozzi, P., Vacchi, M., Bivi, G., Salvador, S., Rossatto, S., Antonioli, F., Asioli, A., Bresolin, M., 2017. Lagoonal settlements and relative sea level during Bronze Age in Northern Adriatic: geoarchaeological evidence and palaeogeographic constraints. Quat. Int. http://dx.doi.org/10.1016/j.quaint.2016.12. 
038

Frezza, V., Carboni, M.G., 2009. Distribution of recent foraminiferal assemblages near the Ombrone River mouth (Northern Tyrrhenian Sea, Italy). Rev. Micropaleontol. 52, 43-66.

Ghilardi, M., Istria, D., Curras, A., Vacchi, M., Contreras, D., Vella, C., Dussouillez, P., Crest, Y., Guiter, F., Delanghe, D., 2017. Reconstructing the landscape evolution and the human occupation of the Lower Sagone River (Western Corsica, France) from the Bronze Age to the Medieval period. J. Archaeol. Sci. Rep. 12, 741-754.

Giaime, M., Avnaim-Katav, S., Morhange, C., Marriner, N., Rostek, F., Porotov, A.V., Baralis, A., Kaniewski, D., Brückner, H., Kelterbaum, D., 2016. Evolution of Taman Peninsula's ancient Bosphorus channels, south-west Russia: deltaic progradation and Greek colonisation. J. Archaeol. Sci. Rep. 5, 327-335.

Hooke, R., Le, B., 2000. On the history of humans as geomorphic agents. Geology 28, 843-846.

Jurko, A., 1958. Pôdne ekologické pomery a lesné spoloćenstvá Podunajskej níziny. Vydavatelstvo Slovenskej akadémie vied, Bratislava, SK.

Lambeck, K., Antonioli, F., Purcell, A., Silenzi, S., 2004. Sea-level change along the Italian coast for the past 10,000 yr. Quat. Sci. Rev. 23 (14), 1567-1598.

Lambeck, K., Antonioli, F., Anzidei, M., Ferranti, L., Leoni, G., Scicchitano, G., Silenzi, S., 2011. Sea level change along the Italian coast during the Holocene and projections for the future. Quat. Int. 232 (1), 250-257.

Lilliu, G., 1999. La civiltà nuragica. Carlo Delfino, Roma.

Marriner, N., Gambin, T., Djamali, M., Morhange, C., Spiteri, M., 2012. Geoarchaeology of the Burmarrad ria and early Holocene human impacts in western Malta. Palaeogeogr. Palaeocl. 339, 52-65.

Marriner, N., Morhange, C., Faivre, S., Flaux, C., Vacchi, M., Miko, S., Rossi, I.R., 2014a. Post-Roman sea-level changes on Pag Island (Adriatic Sea): dating Croatia's "enigmatic" coastal notch? Geomorphology 221, 83-94.

Marriner, N., Morhange, C., Kaniewski, D., Carayon, N., 2014b. Ancient harbour infrastructure in the Levant: tracking the birth and rise of new forms of anthropogenic pressure. Sci. Rep. 4.

Maselli, V., Trincardi, F., 2013. Man made deltas. Sci. Rep. 3.

Masters, P.M., Flemming, N.C., 1982. Quaternary Coastlines and Marine Archaeology. Academic Press, Incorporated.

Murray, J.W., 2006. Ecology and Applications of Benthic Foraminifera. Cambridge University Press, Cambridge.

Orrù, P.E., Antonioli, F., Lambeck, K., Verrubbi, V., 2004. Holocene sea-level change in the Cagliari coastal plain (southern Sardinia, Italy). Quat. Nova 8, 193-212.

Palombo, M.R., Antonioli, F., Presti, V.L., Mannino, M.A., Melis, R.T., Orru, P., Stocchi, P., Talamo, S., Quarta, G., Calacagnile, L., Deiana, G., Altamura, S., 2017. The late Pleistocene to Holocene palaeogeographic evolution of the Porto Conte area: Clues for a better understanding of human colonization of Sardinia and faunal dynamics during the last $30 \mathrm{ka}$. Quat. Int. http://dx.doi.org/10.1016/j.quaint.2016.06.014.

Pérès, J.M., Picard, J., 1964. Noveau manuel de bionomie bentique de la Mer Méditerranée. In: Recueil des Travaux de la Station Marine d'Endoume. 14. pp. $1-114$.

Poher, Y., Ponel, P., Médail, F., Andrieu-Ponel, V., Guiter, F., 2017. Holocene environmental history of a small Mediterranean island in response to sea-level changes, climate and human impact. Palaeogeogr. Palaeocl. 465, 247-263. http://dx.doi.org/ 10.1016/j.palaeo.2016.10.037.

Regione Sardegna, 2017. Sardegna Geoportale, Digital Elevation Models. www. sardegnageoportale.it/index.html.

Reille, M., 1992. Pollen et spores d'Europe et d'Afrique du Nord. Laboratoire de Botanique Historique et Palynologie, URA CNRS 1152, Marseille.

Rossi, V., Amorosi, A., Sarti, G., Potenza, M., 2011. Influence of inherited topography on the Holocene sedimentary evolution of coastal systems: an example from Arno coastal plain (Tuscany, Italy). Geomorphology 135, 117-128.

Sabatier, P., Dezileau, L., Colin, C., Briqueu, L., Bouchette, F., Martinez, P., Siani, G., Reynal, O., Von Grafenstein, U., 2012. 7000 years of palaeostorm activity in the NW Mediterranean Sea in response to Holocene climate events. Quat. Res. 77 (1), 1-11.

Sabato, D., Masi, A., Pepe, C., Ucchesu, M., Peña-Chocarro, L., Usai, A., Giachi, G., Capretti, C., Bacchetta, G., 2015. Archaeobotanical analysis of a Bronze age well from Sardinia: a wealth of knowledge. Plant Biosyst. 149, 205-215.

Sgarrella, F., Moncharmont Zei, M., 1993. Benthic foraminifera of the Gulf of Naples (Italy): systematics and autoecology. Boll. Soc. Paleontol. Ital. 32, 145-264.

Shennan, I., 1986. Flandrian sea-level changes in the Fenland. II: tendencies of sea-levelmovement, altitudinal changes, and local and regional factors. J. Quat. Sci. 1 (2), 155-179.

Stiglitz, A., 1998. Archeologia di un paesaggio: il Sinis (Sardegna centro-occidentale). Atti del $2^{\circ}$ convegno di studi "La ceramica nel Sinis dal neolitico ai giorni nostri". Condaghes, Cagliari, pp. 23-55.

Stuiver, M., Reimer, P.J., Reimer, R.W., 2016. CALIB 7.1. (WWW program) at. http:// calib.org.

Tore, G., Stiglitz, A., 1987. Ricerche archeologiche nel Sinis e nell'alto Oristanese (continuità e trasformazione nell'Evo Antico). In: Mastino, A. (Ed.), L'Africa Romana. Atti del IV convegno di studio, Sassari, pp. 633-658.

Ucchesu, M., Peña-Chocarro, L., Sabato, D., Tanda, G., 2015. Bronze age subsistence in Sardinia, Italy: cultivated plants and wild resources. Veg. Hist. Archaeobotany 24, 343-355.

Ulzega, A., Hearty, P.J., 1986. Geomorphology, stratigraphy and geochronology of Late Quaternary marine deposits in Sardinia. Z. Geomorphol. 62, 119-129.

Usai, A., Sebis, S., Depalmas, A., Melis, R.T., Zedda, M., Carenti, G., Caruso, S., Castangia, G., Chergia, V., Pau, L., Sanna, I., Sechi, S., Serreli, P.F., Soro, L., Vidili, S., Zupancich, A., 2012. L'insediamento nuragico di Sa Osa (Cabras - OR), Atti della XLIV Riunione Scientifica dell'Istituto Italiano di Preistoria e Protostoria La preistoria e la protostoria della Sardegna, II, Firenze. pp. 771-782.

Vacchi, M., Rovere, A., Chatzipetros, A., Zouros, N., Firpo, M., 2014. An updated database of Holocene relative sea level changes in NE Aegean Sea. Quat. Int. 328, 301-310.

Vacchi, M., Marriner, N., Morhange, C., Spada, G., Fontana, A., Rovere, A., 2016. Multiproxy assessment of Holocene relative sea-level changes in the western Mediterranean: sea-level variability and improvements in the definition of the isostatic signal. Earth-Sci. Rev. 155, 172-197.

Vacchi, M., Ghilardi, M., Spada, G., Currás, A., Robresco, S., 2017. New insights into the sea-level evolution in Corsica (NW Mediterranean) since the late Neolithic. J. Archaeol. Sci. Rep. 12, 783-793. 